\title{
Extraspinal ependymoma presenting as a subcutaneous mass posterior to the sacrococcygeal region. Case report
}

\author{
R Inceoğlu MD,${ }^{1} \mathrm{~F}$ Özer MD,${ }^{2} \mathrm{~N}$ Pamir MD,${ }^{3} \mathrm{~S}$ Küllü $\mathrm{MD}^{4}$ \\ ${ }^{1}$ Associate Professor of Surgery, ${ }^{2}$ Associate Professor of Neurosurgery, ${ }^{3}$ Professor of \\ Neurosurgery, ${ }^{4}$ Professor of Pathology, Marmara University School of Medicine, \\ Istanbul, Turkey.
}

\begin{abstract}
Ependymal cells may be found within the coccygeal ligament as well as in heterotopic positions and therefore ependymomas may rarely occur in extraspinal locations. Although the cauda equina is the most common location, less than $5 \%$ of all spinal ependymomas occur extradurally in the sacrococcygeal region. ${ }^{1}$ We report a case of extraspinal myxopapillary ependymoma arising in the subcutaneous soft tissue posterior to the sacrococcygeal region and review the relevant literature.
\end{abstract}

Keywords: ependymoma; extraspinal tumour; sacrococcygeal tumour.

\section{Case report}

A 25 year old female was admitted to our Department of Surgery because of the presence of a slow growing mass in the intergluteal fold for 5 years. On physical examination a round, firm, nontender, totally mobile nodule, $4 \mathrm{~cm}$ in diameter, was discovered in the subcutaneous soft tissue posterior to the sacrum. She was otherwise healthy. Plain xrays and computerised tomography studies did not show bone destruction. Ultrasonography revealed a well defined, nonechogenic, homogenous solid mass, $30 \times 27 \mathrm{~mm}$ in diameter, without showing any relationship to the sacrum (Fig 1).

At operation a highly vascular solid mass, $4 \mathrm{~cm}$ in diameter, was found in the subcutaneous soft tissuc, unattached to the sacrum and with no connection with the spinal canal. Complete local excision was performed. The patient remained free from tumour after 6 months.

Macroscopically the tumour measured $5 \times 4 \times 3 \mathrm{~cm}$ with a well defined nodular surface. The surface showed grey-tan coloured solid tumour. Histological examination revealed florid papillary structures, composed of central acellular connective tissue cores with central blood vessels. Most of these structures were surrounded by low columnar and cuboidal cells (Fig 2). The neoplasm was encapsulated by intact thin fibrous tissue.

Correspondence: Reşit Inceoğlu MD, Eflatun Sokak 8/10, Fenerbahçe Istanbul, 81030 Turkey.

\section{Discussion}

Masses occuring in the sacrococcygeal region often present problems that involve many different specialties, including colorectal surgery, paediatrics, neurosurgery and orthopaedic surgery. An ependymoma arising in the sacrococcygeal region is a rare tumour, which accounts for less than $5 \%$ of all spinal ependymomas. ${ }^{2}$ Extraspinal ependymomas present in two characteristic locations: in the soft tissue posterior to the sacrococcygeal region or in the pelvis anterior to the sacrum. The ages of the patients at onset of symptoms reported in the literature range from 3 months to 65 years, with a mean age of 26 years. ${ }^{1}$ The embryological basis for the origin of the tumour remains obscure. No unitary hypothesis would explain all cases. Wolf points out that the coccygeal medullary vestige, which is an ependyma-lined cavity remaining in the caudal portion of the neural tube beneath the skin of the postnatal pit may be a source of sacrococcygeal ependymomas. ${ }^{3}$ Some have postulated that heteroptic ependymal cell rests may be the source of tumour in some cases, especially those occurring in the dorsal sacrococcygeal region. ${ }^{4.5}$

Extraspinal ependymomas are of the type that were originally labelled as papillary or myxopapillary by Kernohan and FletcherKernohan. ${ }^{2}$ The predominant histological 

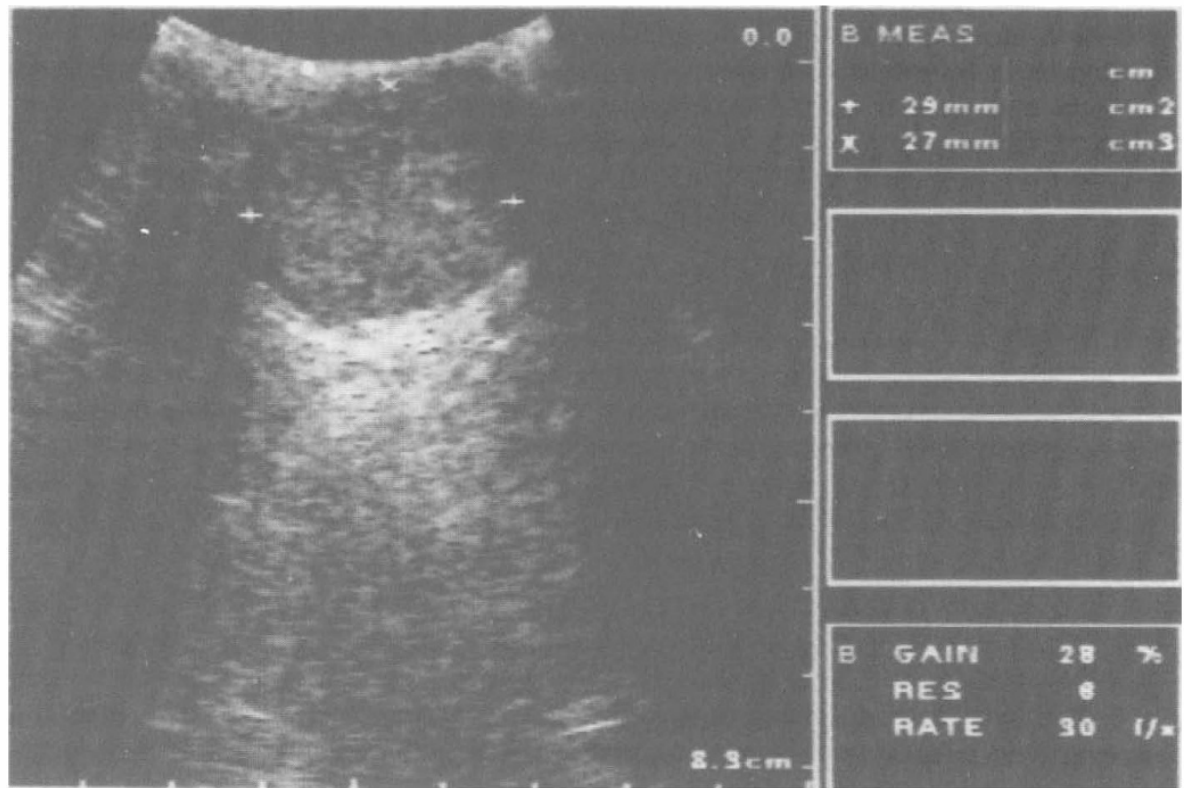

Figure 1 Ultrasonographic appearance of the tumour.

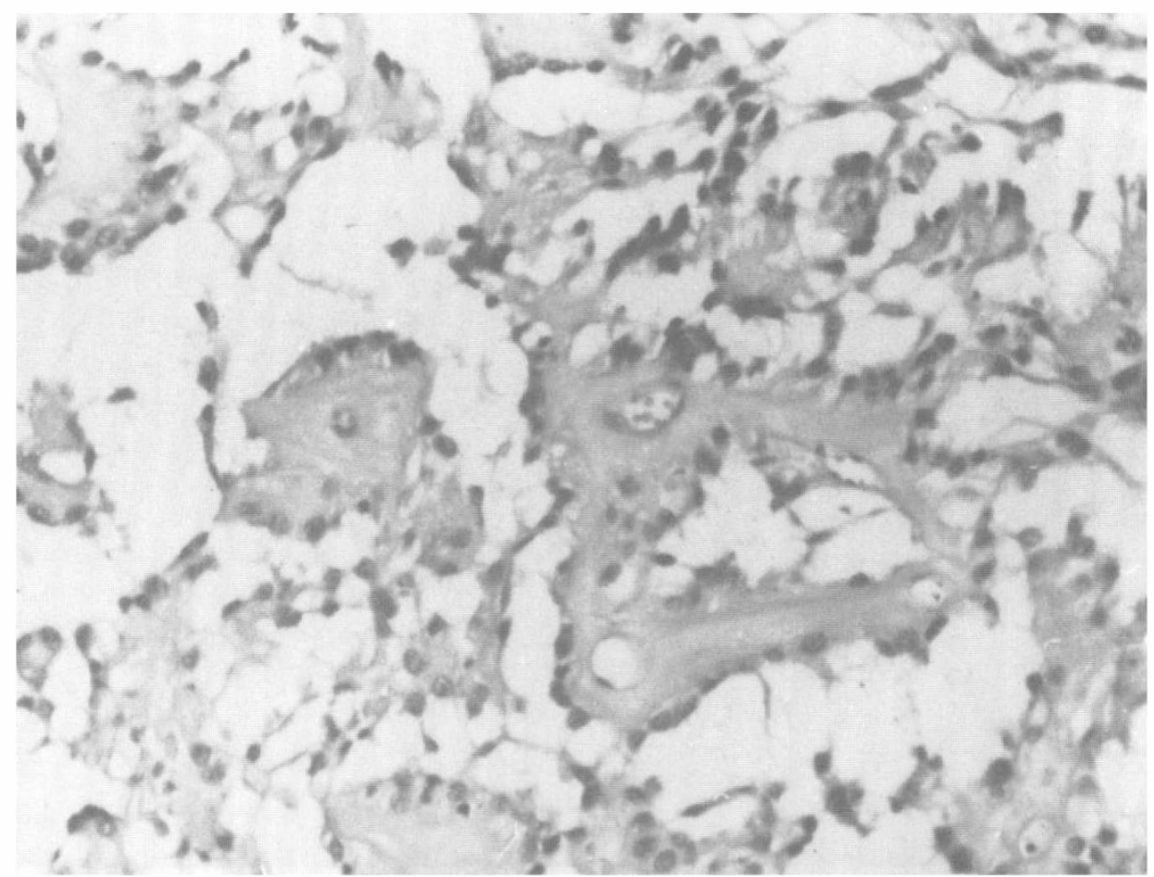

Figure 2 Microscopic photograph of the neoplasm reveals well defined low columnar cells surrounding central cores of acellular connective tissue most of which encloses small blood vessels. $\mathrm{H} \& \mathrm{E}, \times 200$. 
type of ependymoma in the sacrococcygeal region is myxopapillary. ${ }^{5}$ These tumours are highly vascular. ${ }^{4}$ Sacrococcygeal ependymomas characteristically recur locally and tend to metastasise systematically more freqently than do those which are intradural. Because of the increased incidence of systemic metastasis, the average postoperative survival is approximately 10 years. ${ }^{6}$

Based on a review of the literature we concluded that an extraspinal ependymoma is a rare form of tumour which may present as a mass in the subcutaneous soft tissue posterior to the sacrococcygeal region, and is usually mistaken for a pilonidal cyst, lipoma or epidermoid cyst. It is advisable to consider a sacrococcygeal ependymoma as being a low grade malignant tumour and complete local excision should be performed in all cases. Since the tumour may recur locally and tend to metastasise, such patients should be examined periodically.

\section{References}

1 Rengachary SS (1985) Masses of the sacrum. In: Wilkins HR, Rengachany SS, editors. Neurosurgery. Volume III. McGraw-Hill Inc, New York: 1079-1083.

2 Kernohan JW, Fletcher-Kernohan EM (1937) Ependymomas: a study of 109 cases. In: Zabriskie EG, Frantz AM, Hare CC, editors. Tumours of the Nervous System: An Investigation of the Most Recent Advances. Williams \& Wilkins, Baltimore: 182-209.

3 Wolff M, Santiago H, Duby MN (1972) Delayed distance metastasis from a subcutaneous sacrococcygeal ependymoma. Cancer 30: 1046-1067.

4 Anderson MS (1966) Myxopapillary ependymomas presenting in the soft tissue over the sacrococcygeal region. Cancer 19: 585-590.

5 Gerston Gy KF, Suprun H, Shenhav Z (1985) Presacral myxopapillary ependymoma presenting as an abdominal mass in a child. J Pediatr Surg 20: 276-278.

6 Morantz RA, Kepes JJ, Batnitzkys S, Masterson JB (1979) Extraspinal ependymomas. J Neurosurg 51: 383-391. 